BAPTESTINI, JCM; OLIVEIRA, RA; VIDIGAL, SM; PUIATTI, M; CECON, PR. 2018. Onion productivity in relation to irrigation water depths and nitrogen doses. Horticultura Brasileira 36: 073-076. DOI - http://dx.doi.org/10.1590/S0102-053620180112

\title{
Onion productivity in relation to irrigation water depths and nitrogen doses
}

\author{
Júlio Cezar M Baptestini'; Rubens A Oliveira ${ }^{1}$; Sânzio M Vidigal²; Mário Puiatti ${ }^{1}$; Paulo Roberto Cecon ${ }^{1}$
}

'Universidade Federal de Viçosa (UFV), Viçosa-MG, Brazil; julio.baptestini@ifes.edu.br; rubens@ufv.br; mpuiatti@ufv.br; cecon@ufv.br; ${ }^{2}$ Empresa de Pesquisa Agropecuária de Minas Gerais (EPAMIG Zona da Mata), Viçosa-MG, Brazil; sanziomv@epamig.br

\begin{abstract}
Onion is considered the third most important vegetable in terms of economic value in Brazilian horticulture. The factors of production which most limit the productivity of the species are water and nutrients; so, irrigation and soil fertility control are determinant criteria for crop success. The aim of this study was to evaluate the influence of different water depths and nitrogen doses on the productivity of onion, Aquarius hybrid. Five water depths $[(0$, $75,100,125$ and $150 \%$ of crop evapotranspiration (ETc)] and five nitrogen doses $\left(0,120,180,240\right.$ and $300 \mathrm{~kg} \mathrm{ha}^{-1}$, urea form), arranged in a scheme of subdivided plots, in a completely randomized design with four replicates. We used sprinkler irrigation system. Irrigation management and water depths were estimated using Irrigameter. Plants were harvested when more than $60 \%$ of them completed the vegetative period. The water depth corresponding to $150 \%$ of the crop evapotranspiration provided higher total and commercial onion productivities, applying doses of 226.8 and $229.8 \mathrm{~kg} \mathrm{ha}^{-1}$ of nitrogen, respectively.
\end{abstract}

Keywords: Allium cepa, irrigameter, nitrogen fertilization.

\section{RESUMO}

Produtividade de cebola em função de lâminas de água e doses de nitrogênio

A cebola é considerada a terceira hortaliça mais importante em termos de valor econômico na horticultura brasileira. A água e os nutrientes são os fatores de produção que mais limitam a produtividade da espécie, de forma que, o controle da irrigação e da fertilidade do solo são critérios preponderantes para o êxito da cultura. O objetivo neste trabalho foi avaliar a influência de diferentes lâminas de água e doses de nitrogênio sobre a produtividade da cebola, híbrido Aquarius. Foram estudadas cinco lâminas de água $[0,75,100,125$ e 150\% da evapotranspiração da cultura (ETc)] e cinco doses de nitrogênio $(0$, $120,180,240$ e $300 \mathrm{~kg} \mathrm{ha}^{-1}$, na forma de ureia), arranjados no esquema de parcelas subdivididas no espaço, no delineamento inteiramente casualizado, com quatro repetições. A irrigação foi realizada usando-se o método de aspersão. O manejo da irrigação e as lâminas de água foram definidas com uso do Irrigâmetro. A colheita foi realizada quando mais de $60 \%$ das plantas estavam estaladas. A lâmina de água correspondente a $150 \%$ da evapotranspiração da cultura proporcionou maiores produtividades total e comercial da cebola, aplicando-se doses de 226,8 e 229,8 $\mathrm{kg} \mathrm{ha}^{-1}$ de nitrogênio, respectivamente.

Palavras-chave: Allium cepa, irrigação, irrigâmetro, adubação nitrogenada.

\section{Received on October 10, 2016; accepted on April 3, 2017}

$\mathrm{I}^{\mathrm{n}}$ Brazil, onions are the third most important crop, economically speaking, after potatoes and tomatoes (May et al., 2007). The country is the eighth largest onion producer, with about $2 \%$ of the world's supply (Coopercitrus, 2012).

Onion production area was of 56,724 ha in 2016. The production was of $1,563,986$ ton (IBGE, 2017), totaling $28 \mathrm{t} \mathrm{ha}^{-1}$ of productivity. When the onion crop is properly cultivated, yield ranges from 40 to 60 ton, or even higher (Vidigal et al., 2007). In 2012, the national average productivity was of approximately $24.7 \mathrm{t} \mathrm{ha}^{-1}$, being grown in an area of 58,496 ha (IBGE, 2013). Considering the national average productivity, the State of Minas Gerais stands out with $50 \mathrm{t} \mathrm{ha}^{-1}$, in a growing area of 2,200 ha (SEAPA, 2010); most part of this area being in Triângulo Mineiro/Alto Parnaíba Region and the North of Minas, in the Jaíba Project.

Among the practices to maximize the onion production, irrigation is the most used in order to make water available for the crop, according to its physiological necessities. According to Vilas Boas et al. (2011), the right management of this process is indispensable, and it can be adjusted according to the crop conditions. Studies on irrigation of onion show that bulb productivity is highly dependent on the amount of water applied (Santa Olalla et al.,
1994, Shock et al., 2000). Despite the dependence of the onion crop on irrigation, little information about actual water requirements, which allows to promote higher yields, can be found (Oliveira et al., 2013).

Besides irrigation, fertilization is another practice which should be used for growing onion plants. This practice must be executed properly in order to meet the nutritional demand of the crop, though. Fertilization is one of the most economically profitable practices, resulting in higher yield and more unifom products with higher marketable value (Resende et al., 2009). Determining the apropriate fertilization dose is very important since many losses 
of nitrogen and potassium through volatilization and leaching are noticed, and, according to Pôrto et al., (2007) and Vidigal et al., (2010), these are the most absorbed nutrients in percentage of onion dry mass.

Nitrogen contributes to improve onion production, being absorbed in large amounts, only surpassed by potassium (Vidigal et al., 2010). As it participates in protein constitution, nitrogen contributes significantly to the improvement of production and quality of onion bulbs (Factor et al., 2009).

Irrigation and soil fertility control are essential for agriculture success. Among the methods for planning, the use of the response functions allows finding useful solutions in the optimization of water and fertilizers use or in the prediction of crop productivity (Frizzone, 1998). Thus, we observe the importance of studies on irrigation and fertilization for several species of cultivated plants.

In this study we aimed to evaluate the influence of different irrigation water depths and doses of nitrogen related to onion plant production.

\section{MATERIAL AND METHODS}

The experiment was carried out at the Experimental Area of Irrigation and Drainage of Departamento de Engenharia Agrícola, at Universidade Federal de Viçosa, in Viçosa, Brazil ( $20^{\circ} 45^{\prime} \mathrm{S} ; 42^{\circ} 51^{\prime} \mathrm{W}, 651 \mathrm{~m}$ altitude). The experiment lasted 100 days, from July 3 to October 12, 2012.

The split-plot scheme was used, consisting the plots of water depths and subplots of nitrogen doses, in a completely randomized design, with four replicates. Each replicate represented $0.5 \mathrm{~m}^{2}$ of the seedbed area, corresponding to a total of 40 plants. Five irrigation levels were used based on the crop evapotranspiration $(0,75,100$, 125 and $150 \%$ of ETc, corresponding to the total irrigation water depths during the crop cycle of $0 ; 225 ; 300 ; 375$; and $450 \mathrm{~mm}$, respectively) and five nitrogen doses $\left(0,120,180,240\right.$ and $\left.300 \mathrm{~kg} \mathrm{ha}^{-1}\right)$, using urea as source.

The seedbeds were built with dimensions of $15 \mathrm{~m}$ length and $1.2 \mathrm{~m}$ width and spacing of, approximately, 60 $\mathrm{cm}$ between them, making it impossible for the water to move from one to the other. The distance between the split plots, in each seedbed, was $5 \mathrm{~cm}$.

The seedlings were grown in a nursery, in 200-cell styrofoam trays and transplanted when they reached 15 $\mathrm{cm}$ height approximately, at 49 days after sowing, at the beginning of July. Seedlings were put in rows spaced 0.25 $\mathrm{m}$, with spacing $0.10 \mathrm{~m}$ between plants, in the row, being two plants per pit, which corresponded to 800 thousand plants $\mathrm{ha}^{-1}$. The authors used hybrid cultivar called Aquarius, rounded shape, yellow color and high pungency, with an approximated cycle of 150 days.

Nitrogen fertilization was split into three applications of 10, 40 and $50 \%$, at 15,40 and 60 days after transplanting (DAT), respectively (Vidigal et al., 2007). Potassium and nitrogen fertilizations were performed simultaneously, with applications of $250 \mathrm{~kg} \mathrm{ha}^{-1}$ of potassium choride top dressing, according to soil analysis. Each potassium application corresponded to $33.3 \%$ of the total pre-established. Nitrogen and potassium fertilizations were done with the aid of a watering can, with a completely pierced $1 / 2$ "PVC pipe ( $25 \mathrm{~cm}$ long) coupled to the can. The nutrients were diluted in two liters of water and applied to each subplot. Then, the complementation of the water depth was done.

Soil samples were collected at a depth of 0-30 $\mathrm{cm}$ layer before the application of the treatment in order to be chemically analyzed: the following characteristics were verified: $\mathrm{pH}$ $($ water $)=5.45 ; \mathrm{P}=16.5 ; \mathrm{K}=105$ and $\mathrm{Na}=1.4\left(\mathrm{mg} \mathrm{dm}^{-3}\right) ; \mathrm{Ca}^{2+}=2.24 ; \mathrm{Mg}^{2+}=$ $0.58 ; \mathrm{Al}^{3+}=0.0 ; \mathrm{Al}=2.4 ; \mathrm{t}=3.1 ; \mathrm{CTC}=$ 5.5; $\mathrm{SB}=3.1\left(\mathrm{cmol}_{\mathrm{c}} \mathrm{dm}^{-3}\right) ; \mathrm{V}=56.4 \%$ (Embrapa 2011).

Liming and planting fertilization were carried out in all over the experimental area. The area was fertilized with a mixture of $1,500 \mathrm{~kg}$ ha $^{-1}$ of simple superphosphate, $100 \mathrm{~kg}$ $\mathrm{ha}^{-1}$ of potassium chloride, $70 \mathrm{~kg} \mathrm{ha}^{-1}$ of magnesium sulfate, $13 \mathrm{~kg} \mathrm{ha}^{-1}$ of boric acid and $20 \mathrm{~kg} \mathrm{ha}^{-1}$ of zinc sulfate. A plow was used for both operations, adding the components to the soil to a depth of approximately $30 \mathrm{~cm}$.
The Irrigameter technology was used for irrigation water management; the device was installed near the experimental area, which estimates directly the crop evapotranspiration. The Irrigameter has a reservoir which keeps a water depth exposed to atmospheric conditions. Water evaporates simulating the crop evapotranspiration. The reservoir is connected to a glass tube called a feed tube, used to observe the water level and define the time and moment of irrigation. The device operator does not need to calculate anything or consult tables, since the time and moment of irrigation are presented in rulers coupled to the device. A pierced PVC tube was used, whose length was the same as the seedbed width $(1.0 \mathrm{~m})$, diameter $32 \mathrm{~mm}$ and holes spaced of 1 $\mathrm{cm}$. A hydrometer was used to measure the volume of water applied, based on the water depth recommended by the Irrigameter. Total evapotranspiration of the crop was $300 \mathrm{~mm}$ and the total rainfall was $50.7 \mathrm{~mm}$.

A trained person, with constant walking speed, performed the irrigation, carrying a pierced tube, coupled to a hydrometer and connected, through a flexible hose, to the irrigation water reservoir, applying water onto each individual seedbed. As the person walked between the seedbeds, each of them was irrigated individually, without affecting the irrigation of the nearest seedbeds. The irrigation equipment was developed specifically for irrigating the experimental seedbeds; thus, the authors could apply different irrigation depths in each of them.

The relative increase in productivity due to nitrogen fertilization (IRPAN) was determined. In order to evaluate this increase, the authors used the difference between maximum productivity of bulbs (PM), in $\mathrm{kg} \mathrm{ha}^{-1}$ and productivity of bulbs at zero dose (PB zero), divided into necessary $\mathrm{N}$ dose in order to obtain the maximum productivity (PM), through the following fomula:

$$
\begin{aligned}
& \text { IRPAN }=(\text { PM }- \text { PB zero }) /(\text { dose } \\
& \text { for PM })
\end{aligned}
$$

The relative increase in the productivity resulting from the water depth applied (IRPLA) was also calculated. The authors used 
the difference between maximum productivity of bulbs ( $\mathrm{PM})$, in $\mathrm{kg}$ $\mathrm{ha}^{-1}$ and productivity of bulbs at zero water depth (PB zero), divided into the water depth necessary to obtain the maximum productivity (PM), through the following $\mathrm{g}$ formula:

IRPLA $=(\mathrm{PM}-\mathrm{PB}$ zero $) /($ water depth for PM)

To determine the total productivity of onion, the authors considered all the harvested bulbs, including the double ones, attacked by fungi, rotten or showing any type of defect. To determine the marketable productivity, the Ministerial Order No. 529, August 18, 1995, MAPA, was considered. Bulbs showing diameter higher than $3.5 \mathrm{~cm}$ were considered marketable productivity. Bulbs with physical defects, such as rotten, double bulbs and others were excluded.

Data were analyzed using the response surface methodology. The models were chosen based on significance of regression coefficients, using the " $\mathrm{t}$ " test at $5 \%$ probability, for the coefficient of determination and for the behavior of the studied phenomenon.

\section{RESULTS AND DISCUSSION}

The authors determined the inflexion point of maximum total productivity, considering the nitrogen dose; however, this point was not found for applied water depth. The productivity increased as the water depths were increasing (Figure 1), being the maximum with $150 \%$ of crop evapotranspiration (450 $\mathrm{mm}$ ); this was the level of the highest water depth applied considering all the evaluated water depths in the experiment.

The absence of the inflexion point for the water depth is due to the limit established in this study, for water depth levels. As shown in figures 1 and 2 , the point of maximum productivity for the water depth can be obtained in a future experiment evaluating water depth levels higher than $150 \%$ of crop evapotranspiration.

Actually, the irrigation depth applied corresponds to $100 \%$ of ETc, since it is an optimal condition for water reposition in the soil, favoring the crop development in its maximum productivity potential. However, in this

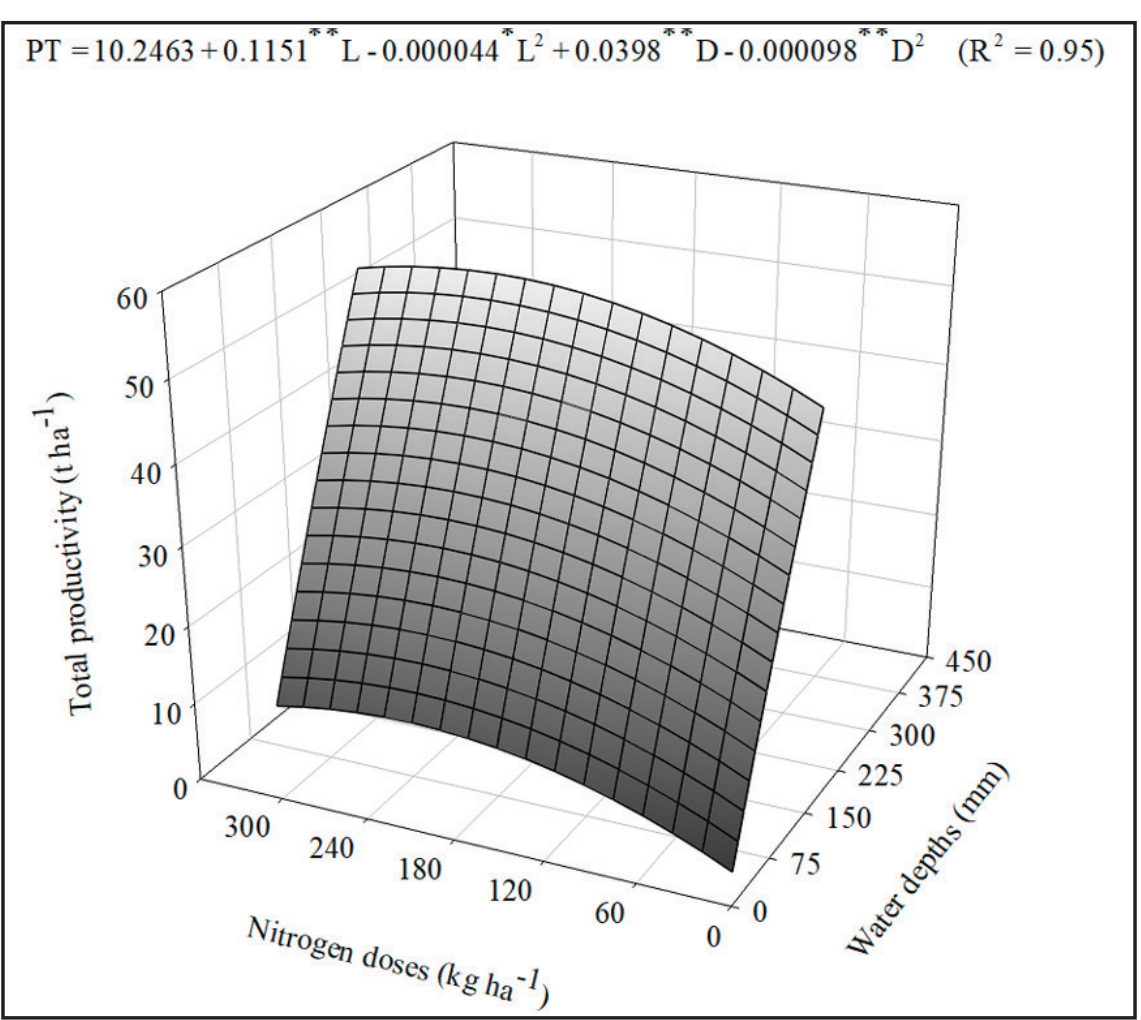

Figure 1. Total productivity of onion bulbs related to nitrogen doses and water depths. Viçosa, UFV, 2012.

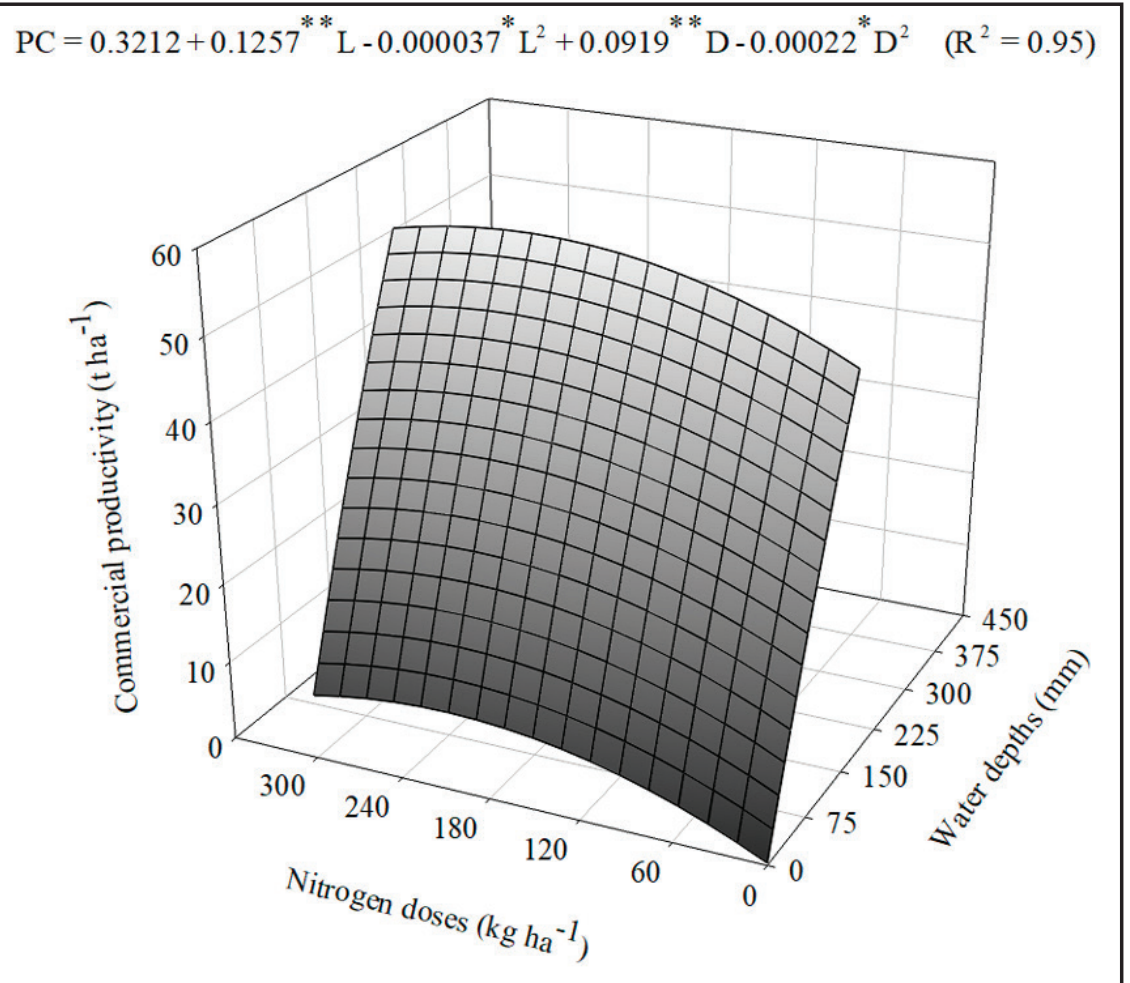

Figure 2. Marketable productivity of onion bulbs related to nitrogen doses and water depths. Viçosa, UFV, 2012. study, water application using irrigation depth of $150 \%$ Etc $(450 \mathrm{~mm})$ was the one which showed better results for total onion bulb productivity. These results 
are in accordance with the ones obtained by Nobile et al. (2012), who worked with different water levels, mineral and organic fertilization, in onion crop. They concluded that the ideal water levels for the crop development are those corresponding to 100 and $150 \%$ of the maximum evapotranspiration considered. Santa Olalla et al. (2004), researching irrigation management in onion, drip irrigated, obtained higher bulb productivities when the soil was kept constantly with high water content.

Vilas Boas et al. (2011), in an experiment carried out in Lavras-MG, using the drip irrigation system in onion, cultivar Alfa Tropical, applying water depth of $615 \mathrm{~mm}$, maximum productivity of $39.5 \mathrm{t} \mathrm{ha}^{-1}$ was obtained. Using cultivar Optima F1 and applying water depth of $603.6 \mathrm{~mm}$, obtained maximum onion productivity of $57.8 \mathrm{t}$ $\mathrm{ha}^{-1}$. For cv. hybrid Aquarius, in order to obtain similar productivity, a water depth of only $242 \mathrm{~mm}$ and $226.8 \mathrm{~kg} \mathrm{ha}^{-1}$ of $\mathrm{N}$ is necessary.

The nitrogen dose corresponding to $226.8 \mathrm{~kg} \mathrm{ha}^{-1}$ resulted into a maximum total productivity of bulbs $\left(60.7 \mathrm{tha}^{-1}\right)$. This dose and water depth equivalent to $100 \%$ of ETc $(300 \mathrm{~mm})$ corresponded to total bulb onion productivity of 45.5 $\mathrm{t} \mathrm{ha}^{-1}$ (Figure 1). Considering the water depth of $450 \mathrm{~mm}$ and dose of $226.8 \mathrm{~kg}$ ha $^{-1}$ of $\mathrm{N}$, total productivity was of 59.4 $\mathrm{t} \mathrm{ha}^{-1}$. This productivity corresponds to $13.9 \mathrm{t} \mathrm{ha}^{-1}$ or $30.6 \%$ more onion bulbs than that one obtained applying water depth of $300 \mathrm{~mm}$ and $226.8 \mathrm{~kg} \mathrm{ha}^{-1}$ of N.

The total productivity obtained was much higher than the Brazilian average for conventional crops, which is 17 $\mathrm{t} \mathrm{ha}^{-1}$ (Vilela et al., 2005), as well as the average obtained by Pereira et al. (2002), $22 \mathrm{t} \mathrm{ha}^{-1}$, with application of $20 \mathrm{t} \mathrm{ha}^{-1}$ of cattle manure as organic fertilization, in a colder region in the South of Minas Gerais State, though.

The relative increase in the total productivity due to nitrogen fertilization corresponded to $56.4 \mathrm{~kg}$ of onion per $\mathrm{kg}$ of $\mathrm{N}$, whereas the relative increase in total productivity due to water depth was of $113.3 \mathrm{~kg}$ of onion per unit of water depth (mm).

The nitrogen dose which resulted in maximum marketable productivity corresponds to $229.8 \mathrm{~kg} \mathrm{ha}^{-1}$ (Figure 2). Considering the dose of $\mathrm{N}$ which resulted in the maximum marketable productivity $\left(229.8 \mathrm{~kg} \mathrm{ha}^{-1}\right)$ and water depth equivalent to $100 \%$ of ETc, marketable productivity of $45.6 \mathrm{t} \mathrm{ha}^{-1}$ of onion bulbs was obtained.

Considering the depth of 450 $\mathrm{mm}$ and dose of $229.8 \mathrm{~kg} \mathrm{ha}^{-1}$ of $\mathrm{N}$, the authors obtained marketable productivity of $60.7 \mathrm{t} \mathrm{ha}^{-1}$ of onion bulbs. This productivity corresponds to $15.1 \mathrm{t} \mathrm{ha}^{-1}$ more onion bulbs than the obtained with the application of water depth of $300 \mathrm{~mm}(100 \%$ of ETc) and $229.8 \mathrm{~kg} \mathrm{ha}^{-1}$ of $\mathrm{N}$. This corresponds to an increase of $33.1 \%$, it means, 755 bags of onion per hectare.

The authors recommend the application of $150 \%$ of water depth, with $229.8 \mathrm{~kg} \mathrm{ha}^{-1}$ of $\mathrm{N}$ in each irrigation when the Irrigameter is used. This process allows higher onion productivity.

The control of the water depth and the nitrogen dose applied to onion crop is extremely important, since the rigor of its application brings great productive and economic advantages to onion producers.

\section{ACKNOWLEDGEMENTS}

The authors thank to Foundation for research support of Minas Gerais for supporting the research, to all friends, trainées and employees of UFV and EPAMIG, which helped out in this study.

\section{REFERENCES}

Coopercitrus Revista Agropecuária. 2015. Cebola: Terceira hortaliça mais produzida no mundo. Available at http://www. revista coopercitrus. com.br/?pag $=$ materia\&codigo $=6177 /$. Accessed February 10, 2015

Embrapa. 2011. Manual de métodos de análise do solo. 2.ed. Revisada. Rio de Janeiro: EMBRAPA Centro Nacional de Pesquisa de Solos. $230 \mathrm{p}$.

FACTOR TL, LIMA JRS, PURQUERIO LFV, TIVELLI SW, TRANI PE, BREDA JRJM, ROCHA MAV. 2009. Manejo da adubação nitrogenada na produção de cebola em plantio direto. Horticultura Brasileira 27: S613-S620.

FRIZZONE JA. 1998. Função de produção. In: CONGRESSO BRASILEIRO DE ENGENHARIA AGRÍCOLA, 27. Annals... Poços de Caldas, MG: Sociedade Brasileira de Engenharia Agrícola, p. 87.

IBGE. 2017. Available at https://sidra.ibge.gov. br/tabela/1618\#resultado. Accessed February 28,2015

IBGE. 2013. Produção agrícola municipal. Available at http://www.ibge.gov.br/.Accessed August 11, 2015

MAY A, CECILIO FILHO AB, PORTO DRQ, VARGAS PF, BARBOSA JC. 2007. Produtividade de híbridos de cebola em função da população de plantas e da fertilização nitrogenada e potássica. Horticultura Brasileira 25: 053-059.

NOBILE FO, GALBIATTI JA, MURAISHI RI, SPADONI TB. 2012. Biofertilizante e adubação mineral no desenvolvimento da cultura da cebola (Allium cepa L.) irrigada com duas lâminas de água. Nucleus 9: 27-34.

OLIVEIRA GM, LEITÃO MMBR, BISPO RC, SANTOS IMS, LIMA CBA, CARVALHO ARP. 2013. Coeficiente de cultura e produtividade da cebola submetida a diferentes lâminas de irrigação. Revista Brasileira de Engenharia Agrícola e Ambiental. 17: 969974.

PEREIRA AJ, SOUZA RJ, PEREIRA WR. 2002. Efeito de diferentes doses de esterco de galinha e de curral sobre a produção de cebola. Horticultura Brasileira 20: Suplemento CDROM.

PÔRTO DRQ, CECILIO FILHO AB, MAY A, VARGAS PF. 2007. Acúmulo de macronutrientes pela cultivar de cebola "Superex" estabelecida por semeadura direta. Ciência Rural. 37: 949-955.

RESENDE GM, COSTA ND, PINTO JM. 2009. Rendimento e conservação pós-colheita de bulbos de cebola com doses de nitrogênio e potássio. Horticultura Brasileira. 27: 139-143.

SANTA OLALLAFM, DOMINGUEZ-PADILLA A, LOPEZ R. 2004. Production and quality of onion crop (Allium cepa L.) cultivated in semiarid climate. Agricultural Water Management 68: 77-89.

SANTA OLALLA FM, VALERO JAJ, CORTES CF. 1994. Growth and production of onion crop (Allium cepa L.) under different irrigation scheduling. European Journal of Agronomy 3: 85-92.

SEAPA - Secretaria de Agricultura, Pecuária e Abastecimento de Minas Gerais. 2010. Perfil do agronegócio (2003-2009). Belo Horizonte: Secretaria de Agricultura, Pecuária e Abastecimento de Minas Gerais, 142 p.

SHOCK CC, FEIBERT EBG, SAUNDERS LD. 2000. Irrigation criteria for rip irrigated onions. HortScience 35: 63-66.

VIDIGAL SM, COSTA EL, CIOCIOLA JÚNIOR AI. 2007. Cebola (Allium cepa L.). In: PAULA JÚNIOR TJ, VENZON M (org). 101 culturas - Manual de Tecnologias Agrícolas. Belo Horizonte: EPAMIG, p. 243-252.

VIDIGAL SM, PEDROSA MW, FONSECA MS, SANTOS IC. 2010. Adubação com nitrogênio em cobertura na produção de cebola. Horticultura Brasileira 28: S3705-S3711.

VILAS BOAS RC, PEREIRA GM, SOUZA RJ, CONSONI R. 2011. Desempenho de cultivares de cebola em função do manejo da irrigação por gotejamento. Revista Brasileira de Engenharia Agrícola e Ambiental 15: 117-124. 